Article

\title{
Reuse of Excavated Clayey Silt in Cement-Fly Ash-Bentonite Hybrid Back-fill Grouting during Shield Tunneling
}

\author{
Jun $\mathrm{Xu}^{1}$, Chao Xiao ${ }^{1,2, *}$, Huai-Na Wu ${ }^{1,3,4}$ and Xin Kang ${ }^{1,3,4}$ \\ 1 College of Civil Engineering, Hunan University, Changsha 410082, China; junxu@hnu.edu.cn (J.X.); \\ wuhn@hnu.edu.cn (H-N.W.); kangxin@hnu.edu.cn (X.K.) \\ 2 China Construction Tunnel Co., Ltd, Chongqing 401320, China \\ 3 Key Laboratory of Building Safety and Energy Efficiency of the Ministry of Education, Hunan University, \\ Changsha 410082, China \\ 4 National Center for International Research Collaboration in Building Safety and Environment (NCIRCBSE), \\ Hunan University, Changsha 410082, China \\ * Correspondence: hnuxiaochao@hnu.edu.cn
}

Received: 27 December 2019; Accepted: 28 January 2020; Published: 31 January 2020

\begin{abstract}
Excavated soils from tunnel construction need high treatment cost and pollute the environment. To investigate the feasibility of excavated clayey silt reused in back-fill grout, the flowability, stability and strength were taken as measurement indexes of grouting performance. The clayey silt was tested to be reused as substitutes for fly ash, bentonite and sand, respectively. The experimental results indicated that the clayey silt reused as a substitute for fly ash decreased the flowability and strength of grout mixes, and the clayey silt reused as a substitute for bentonite decreased the stability of grout mixes, and neither of them was feasible. The clayey silt reused as a substitute for sand decreased the flowability, but the grouting performance could be improved by adjusting the mix proportion to meet all grouting requirements. After adding the proportion of water to improve the flowability and increasing the cement:fly ash ratio to improve the strength, a scheme of clayey silt reutilization was suggested, which was cement:fly ash:bentonite:clayey silt:water = 280:230:100:680:660. At the end of this paper, the pore structure feature tests, X-ray diffraction (XRD) tests and scanning electron microscope (SEM) tests were performed to analyze the different morphology, microstructure and mineralogy characteristics before and after the clayey silt was reused as a total substitute for sand in grout mixes.
\end{abstract}

Keywords: grouting materials; clayey silt; flowability; stability; strength

\section{Introduction}

Due to the fast development of city transportation construction, shield tunneling has been extensively used in the development of underground infrastructure [1-3]. When tunneling is carried out, the soils are broken up by a shield cutterhead and hauled away by a conveying system along with the process of shield machine advancing. A great deal of excavated soils needs to be transported from construction site to disposal area, which costs a lot of money and pollutes the environment due to leakage and dust. Since the outside diameter of the shield is larger than that of the segmental lining, the circular cylindrical gap between segments and soil must be sealed after the shield tail is separated [4,5]. The gap between the segment lining and soil can be up to $20 \mathrm{~cm}$ in width [6]. This annular gap has to be immediately backfilled with suitable grouts to avoid the presence of voids around the tunnel during the TBM (Tunnel Boring Machines) advance that can induce settlements at the ground surface [7-9]. Back-fill grout can also hold the segmental lining in position by bearing the load 
between the ground and the TBM itself, and strengthen the waterproof function of the tunnel $[10,11]$. If excavated soils are recycled in back-fill grouting, not only can this reduce the cost of purchasing grouting materials and disposing of excavated soils, but it can also lessen the environment pollution and realize resource reutilization.

According to the classification proposed by Thewes and Budach [12] and following the scheme proposed by EFNARC (European Federation for Specialist Construction Chemicals and Concrete Systems) [13], back-fill grouting in tunnel construction can be divided into three types: inert mixes, cement mixes and two component mixes. The inert mix is based on sand mixing with other constituents, such as filler, lime, fly ash, etc. The cementitious mix is constituted by water, cement, bentonite and chemical admixtures. The two-component mix is typically composed of two components, where one is made up of cement, water, bentonite and retarder, and the other is made up of sodium silicate and water. The two-component mix begins to gel and starts to attain mechanical strength within a few minutes after mixing $[10,14]$. In China, the cementitious mixes are widely used in synchronous grouting and the two-component mixes are used to reinforce the defective areas after synchronous grouting. The evaluation indexes of grout mixes mainly consisted of workability, flowability, stability, pumpability and strength according to former researches [15-17], but not all indexes are needed to measure grout performance. In this research, flowability, stability and strength were picked as the evaluation indexes.

Natural sand is the most common fine aggregate, which was widely used in the production of mortar and concrete. In the last 20 years, it has become clear that the availability of good quality natural sand is decreasing. The shortage of the resources of natural sand had opened the possibility for the use of cementitious materials to replace part of the sand. There were many studies about multifarious materials as replacement of sand in mortar and concrete [18-22]. Nambiar and Ramamurthy [23] replaced natural sand with FA (Fly Ash) in foam concrete. The results indicated that the foam concrete with FA as filler gave relatively higher flow values and compressive strengths. Rashad [24] used metakaolin (MK) as a fine aggregate replacement to replace sand in concrete. The test results indicated that compressive strength, splitting tensile strength and abrasion resistance of concrete mixtures increased with increasing content of fine aggregate replacement with MK. Zhang et al. [25] improved a controllable paste grout, which used clay instead of sand and was mixed with cement and modifier to satisfy the requirements of filling and grouting the water rich karst for subsequent shield tunneling. These studies have proven the probability that the sand in cement or mortar can be replaced by other materials.

In recent years, the reuse of construction waste in cement or mortar has become a hot topic. Zhong et al. [26] investigated the possibility of discharged fine sand being reused in back-fill grouting by changing the grain composition of fine sand. Experimental results showed the excavated fine sand could be reused in back-fill grouting. Aboutabikh et al. [27] offered a solution for the recycling and reuse of treated oil sand drill cutting waste in grout manufacture. Kassem et al. [28] used treated oil sand waste in a concrete mixture, leading to a less harmful environment impact. Shinde et al. [29] reused marble dust and granite dust in injection grouts, which reduced the cost of grout by $70 \%$ to $75 \%$ less than market cost. Zhou et al. [30] confirmed the feasibility of discharged sandy soil from a slurry shield tunnel as a material of back-fill grout. Çınar et al. [31] investigated the effect of waste marble powder on the fluidity of cement based grout mixtures and found $15 \%$ was the upper limit of reutilization. In the field of tunnel construction, current research achievements mainly focus on excavated sand or sandy soil replacing sand in grout mixes. The research of using excavated non-sandy soil to replace sand in grout mixes is insufficient, and the feasibility of other materials except for sand in grout mixes being replaced by excavated soil is not clear. The research about clayey silt from excavated soil reused in back-fill grouts would provide a new perspective and probability of waste reutilization in tunnel construction.

In this study, clayey silt excavated from a shield tunneling construction site was used as a substitute for raw materials in a cement mix, which consisted of cement, fly ash, bentonite and sand. 
The investigation mainly focused on the influences of flowability, stability and strength after clayey silt was reused as a substitute for fly ash, bentonite and sand. After that, a program of excavated clayey silt reutilization in back-fill grouting was proposed. Furthermore, the pore structure features were analyzed by taking pictures of $2 \mathrm{D}$ sections of specimens; the microcosmic characteristics of traditional grouts and recycled grouts were tested by the technique of X-ray diffraction (XRD) and scanning electron microscopy (SEM) to analyze the change of hydration products.

\section{Experimental Materials and Methods}

\subsection{Experimental Materials}

The excavated soils in this study were taken from a construction site in Zhengzhou metro line 3 zone 6, where the major stratigraphic condition the shield tunneling machine went through was clayey silt. Foam and bentonite were added into the soil to form a state of plastic flow soil during the earth pressure balance (EPB) shield excavation. The excavated soils (clayey silt) were transported from the soil bin in the EPB shield machine to a residue pond on the ground. The clayey silt used in this study was taken from the residue pond, as shown in Figure 1, of which the specific gravity was 2.70, the dry density was $1680 \mathrm{~kg} / \mathrm{m}^{3}$ and the liquid and plastic limit were $24.1 \%$ and $15.4 \%$, respectively.

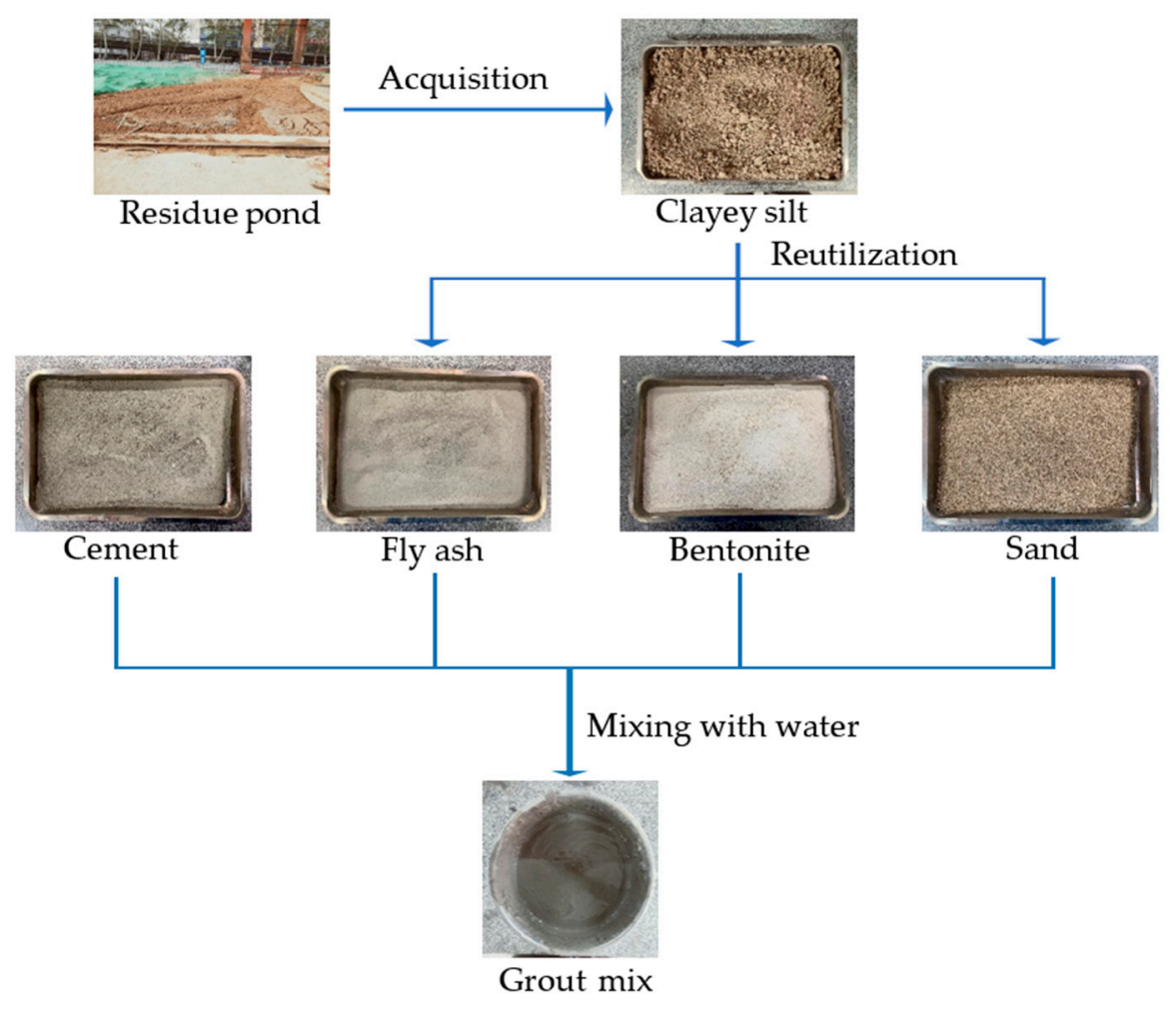

Figure 1. Pictures of raw materials and grout mix.

The cement used in this study was ordinary Portland cement (P.O 42.5), supplied by South Cement Company United. The fly ash used was type $\mathrm{F}$ in the amount of calcium oxide and level I in fineness. The bentonite used was Na-bentonite and the number of swelling ratio was 40 . The sand used was river sand between the mesh numbers of 40 to 70 . All of the materials used in this paper are presented in Figure 1. The particle size distribution of these raw materials was tested by a laser particle size analyzer and a series of soil sieves, as plotted in Figure 2. The oxide composition of raw materials was analyzed by X-ray fluorescence (XRF) tests, and the results are listed in Table 1. 


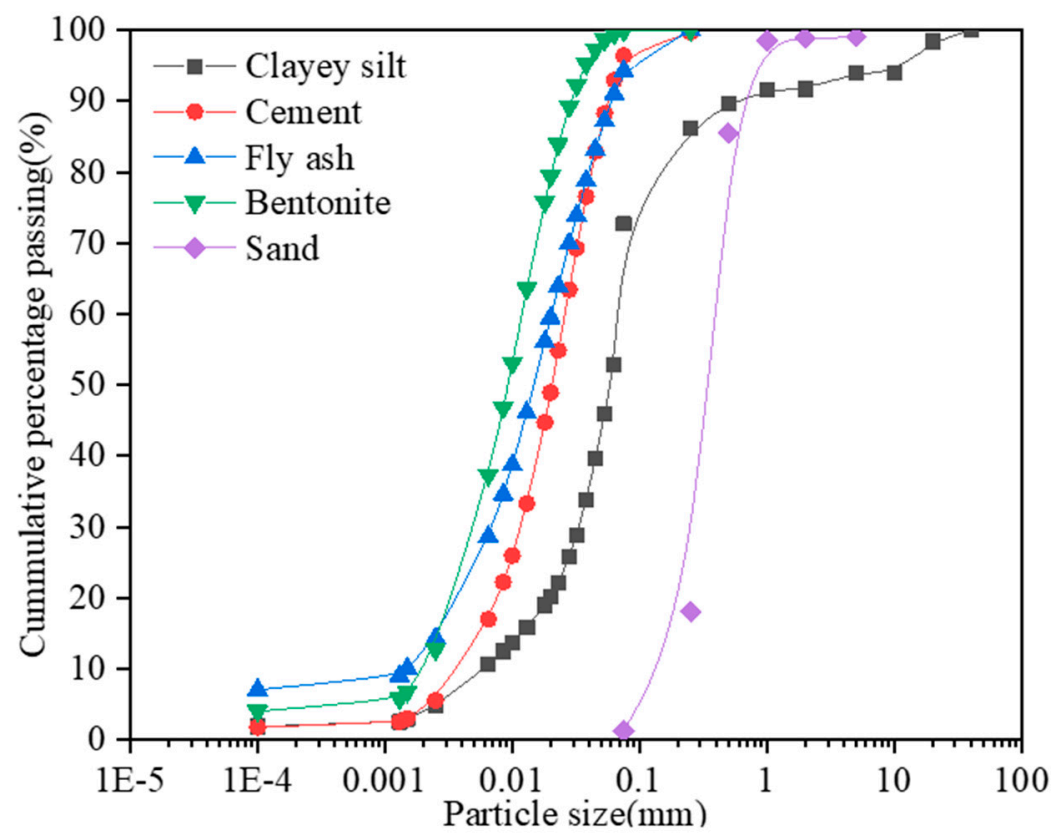

Figure 2. Particle size distribution of raw materials.

Table 1. Oxide composition of raw materials.

\begin{tabular}{ccccccccccc}
\hline \multirow{2}{*}{$\begin{array}{c}\text { Raw } \\
\text { Material }\end{array}$} & $\mathbf{S i O}_{\mathbf{2}}$ & $\mathbf{F e}_{\mathbf{2}} \mathbf{O}_{\mathbf{3}}$ & $\mathbf{A l}_{\mathbf{2}} \mathbf{O}_{\mathbf{3}}$ & $\mathbf{M g O}$ & $\mathbf{S O}_{\mathbf{3}}$ & $\mathbf{C a O}$ & $\mathbf{N a}_{\mathbf{2}} \mathbf{O}$ & $\mathbf{K}_{\mathbf{2}} \mathbf{O}$ & $\mathbf{T i O}_{\mathbf{2}}$ & $\mathbf{P}_{\mathbf{2}} \mathbf{O}_{\mathbf{5}}$ \\
\hline Cement & 17.02 & 3.75 & 3.62 & 1.59 & 2.99 & 69.21 & 0.08 & 0.83 & 0.26 & 0.13 \\
Fly ash & 48.02 & 6.95 & 35 & 0.4 & 1.6 & 4.13 & 0.3 & 1.21 & 1.71 & 0.36 \\
Bentonite & 55.45 & 1.95 & 37.52 & 0.27 & 0.12 & 0.04 & 0.09 & 3.91 & 0.45 & 0.05 \\
Sand & 69.11 & 3.9 & 13.97 & 1.3 & 0.04 & 3.35 & 3.06 & 4.42 & 0.39 & 0.09 \\
Clayey silt & 65.35 & 5.07 & 13.68 & 1.98 & 0.07 & 8.21 & 1.35 & 3.03 & 0.85 & 0.19 \\
\hline
\end{tabular}

\subsection{Experimental Methods}

\subsubsection{Flowability Test}

Consistency was regarded as a parameter of flowability in some research [32,33]. Slump diameter has been considered as a measurement index of flowability for a long time [34]. Grout-flow cone efflux time, which is often tested by marsh cone, could also be a parameter linked to flowability [35,36]. The flowability of grout mixes was evaluated by the combination of consistency, slump diameter and grout-flow cone efflux time in this research.

The consistency of grout mixes was measured according to the Chinese standard (JGJ/T 70-2009). The apparatus of the consistency test is shown in Figure 3a. Before the experiment, the surfaces of the test cone and the container were wiped by a damp cloth. Then grout mix was loaded into the container at one time. A slender iron rod was used to tamp the mixture 25 times from the center to the edge of the container evenly; then the container was shaken 5 to 6 times to smooth the mixture surface before the container was placed on the base. The number on the dial plate was recorded when the test cone was adjusted to be in contact with the surface of the grout mix, and then the slider was released to make it free to fall. The number on the dial plate was recorded again after 10 seconds. The difference between two records was the consistency. The average of two measurements was calculated as the final result. The consistency was tested at $0 \mathrm{~h}, 3 \mathrm{~h}, 6 \mathrm{~h}$ and $9 \mathrm{~h}$ after materials were mixed, respectively. 

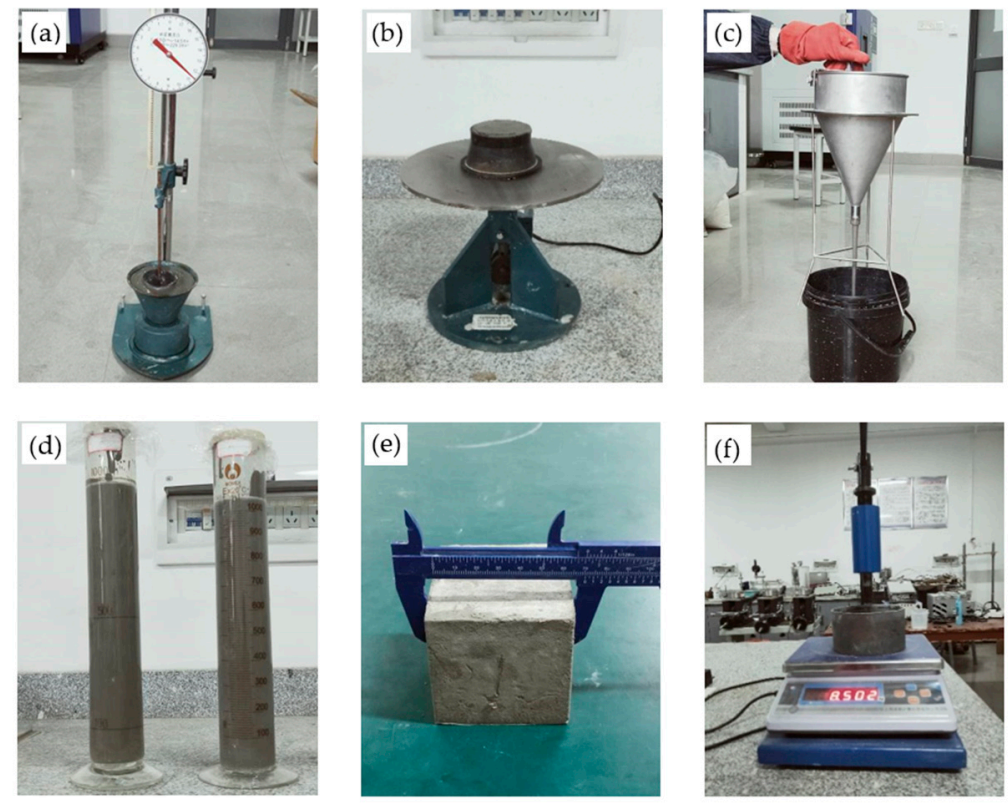

Figure 3. Apparatus of grouting performance test (a) consistency, (b) slump diameter, (c) grout-flow cone efflux time, (d) bleeding rate, (e) volume shrinkage rate, (f) final setting time.

The slump diameter test was conducted according to the Chinese standard (GB/T 2419-2005). The apparatus of slump diameter test is shown in Figure $3 \mathrm{~b}$. The diameter of the countertop was $300 \mathrm{~mm}$. A truncated cone mold with $60 \mathrm{~mm}$ in height, $70 \mathrm{~mm}$ in upper opening and $100 \mathrm{~mm}$ in bottom opening, was put in the middle of the countertop. The surface of the countertop and the internal face of the truncated cone mold were wiped by a damp cloth before the experiment. After that, grout mix was loaded into the truncated cone mold at twice together with tamping by a slender iron rod. Then the mold was removed and the machine was turned on to let the countertop throb for 25 times. The spread diameter of grout mix, recorded as slump diameter, needed to be measured immediately after the throbbing. The spread diameter was tested at $0 \mathrm{~h}, 3 \mathrm{~h}, 6 \mathrm{~h}$ and $9 \mathrm{~h}$, respectively.

The grout-flow cone efflux time test was conducted according to the Chinese standard (JTG E30-2005). The apparatus of grout-flow cone efflux time test is shown in Figure 3c, which was an obconical funnel. The obconical funnel was about $1725 \mathrm{~mL}$ in volume and the diameter of the outlet in the bottom was about $12.7 \mathrm{~mm}$. Before the experiment, the internal face of the funnel was wiped by a damp cloth. The grout mix was loaded into the funnel until it reached the line of marked height. Then the time was recorded from the release at the outlet until the grout mix ran down, which was grout-flow cone efflux time. Considering the flowability loss of the grout mix, the grout-flow cone efflux time was only tested at $0 \mathrm{~h}$, following the preparation of grout mix.

\subsubsection{Stability Test}

The bleeding rate test of grout mix was conducted based on the Chinese standard (JC/T 2153-2012). Grout mixes were loaded into a $1000 \mathrm{~mL}$ graduated cylinder, as shown in Figure 3d. The water floating on the surface of the grout mix was suck out with a straw after 3 hours. The mass ratio of floated water to total water was the bleeding rate.

The volume shrinkage rate was measured by the loss ratio of sample volume after 28-day natural curing. The shrinkage volume was measured by a Vernier caliper, as shown in Figure 3e. The size before curing was $70.7 \mathrm{~mm} \times 70.7 \mathrm{~mm} \times 70.7 \mathrm{~mm}$, which was the same as the test mold.

\subsubsection{Strength Test}

The strength can be evaluated based on final setting time and unconfined compression strength [37]. The final setting time was measured according to the Chinese standard (JGJ/T 70-2009). Grout mixes 
were placed in a cylinder container, which was put on an electronic weighing scale, as shown in Figure 3f. There was a test needle with length of $25 \mathrm{~mm}$ and sectional area of $30 \mathrm{~mm}^{2}$ above the cylinder container. The reading of the scale was reset after the cylinder container was put on the scale, and then the lever was pressed down evenly which lasted for 10 seconds. The number of the scale was recorded as the penetration resistance. The time when the penetration resistance arrived at $15 \mathrm{~N}$ was the final setting time.

The UCS (Unconfined Compression Strength) was measured according to the Chinese standard (JGJ/T 70-2009). Grout mixes were casted into cube molds with dimension of $70.7 \mathrm{~mm} \times 70.7 \mathrm{~mm} \times 70.7 \mathrm{~mm}$, followed by shaking them manually. Then specimens were put in a constant temperature and constant humidity box $\left(\mathrm{T}=20^{\circ} \mathrm{C}\right.$ and $\left.\mathrm{RH}=90 \%\right)$ for $24 \mathrm{~h}$. After demolding, the specimens were transferred to a natural curing stage $\left(\mathrm{T}=20^{\circ} \mathrm{C}\right.$ and $\left.\mathrm{RH}=70 \pm 5 \%\right)$ until UCS tests were conducted. The UCS was tested at $1 \mathrm{~d}, 7 \mathrm{~d}$ and $28 \mathrm{~d}$, respectively, by using a universal tester at loading rate of $250 \mathrm{~N} / \mathrm{s}$. The mean value of three samples was interpreted as measured UCS.

\subsection{Experimental Schemes}

Traditionally, the water:cement ratio is probably the most important parameter within concrete technology. Mortar and concrete properties can often be predicted by considering the water:cement ratio as the governing parameter [38]. Besides the water cement ratio, the cement content is often used as an important influencing parameter, related with mechanical and physical properties of the resulting mortar and concrete. The influence of the aggregates in mortar or concrete is not so well documented as the influence of the cement content and water:cement ratio [39,40]. In this research, the experimental schemes were laid down step by step, improving the grouting performance by adjusting the water content and the cement:fly ash ratio to meet all grouting performance requirements.

The experimental schemes consisted of three parts. The grout mixes of all schemes needed to test flowability, stability and strength. The first part was to define a reasonable range for grouting performance parameters. The basic mix proportion of traditional grout mix was from the construction site in Zhengzhou, consisting of cement $\left(130 \mathrm{~kg} / \mathrm{m}^{3}\right)$, fly ash $\left(380 \mathrm{~kg} / \mathrm{m}^{3}\right)$, bentonite $\left(100 \mathrm{~kg} / \mathrm{m}^{3}\right)$, sand $\left(680 \mathrm{~kg} / \mathrm{m}^{3}\right)$ and water $\left(510 \mathrm{~kg} / \mathrm{m}^{3}\right)$. This mix proportion was just a reference; workers in mixing stations would adjust the proportion according to the construction requests. For the purpose of getting a typical mix proportion and providing appropriate demands of grouting performance for later research, it was necessary to adjust the water content to formulate different types of grouts. As shown in Table 2, grout mixes experienced a status from over wet to over dried along with the decreased component of water from $\mathrm{T} 1$ to $\mathrm{T} 4$. In this table, ' $\mathrm{T}$ ' means traditional grout mixes and the number from 1 to 4 means the different water added from $510 \mathrm{~g}$ to $360 \mathrm{~g}$.

Table 2. Experimental schemes of determining grouting performance parameter.

\begin{tabular}{ccccccc}
\hline Type & Term of Mix & Cement $(g)$ & Fly Ash $(g)$ & Bentonite (g) & Sand (g) & Water (g) \\
\hline \multirow{3}{*}{ Traditional } & T1 & 130 & 380 & 100 & 680 & 510 \\
grout mixes & T2 & 130 & 380 & 100 & 680 & 460 \\
& T3 & 130 & 380 & 100 & 680 & 410 \\
& T4 & 130 & 380 & 100 & 680 & 360 \\
\hline
\end{tabular}

The second part was to research the influence on grouting performance when clayey silt was reused as substitute for traditional materials in grout mixes. Combining the results of particle size distribution in Figure 2 and chemical composition comparison in Table 1, it was possible that clayey silt be reused as a substitute for fly ash, bentonite or sand. In order to evaluate grouting performance after the addition of clayey silt, the aforesaid three grout materials were replaced by clayey silt at equal increment $(20 \%)$ to keep single variable criteria. The experimental schemes are shown in Table 3. In this table, the symbols of ' $\mathrm{F}$ ', 'B' and ' $\mathrm{S}$ ' mean clayey silt as substitute for fly ash, bentonite and sand, respectively. The number from 1 to 5 means the replacement ratio increases from $20 \%$ to $100 \%$. In this 
table, the amount of water added is $460 \mathrm{~g}$, based on the mix proportion of $\mathrm{T} 2$, which has an excellent grouting performance according to the experimental results of Table 2.

Table 3. Experimental schemes of clayey silt reused as substitute for traditional raw materials.

\begin{tabular}{|c|c|c|c|c|c|c|c|}
\hline Type & $\begin{array}{c}\text { Term of } \\
\text { Mix }\end{array}$ & $\begin{array}{c}\text { Cement } \\
\text { (g) }\end{array}$ & $\begin{array}{c}\text { Fly Ash } \\
\text { (g) }\end{array}$ & $\begin{array}{c}\text { Bentonite } \\
\text { (g) }\end{array}$ & $\begin{array}{c}\text { Sand } \\
(\mathrm{g})\end{array}$ & $\begin{array}{l}\text { Water } \\
\text { (g) }\end{array}$ & $\begin{array}{c}\text { Clayey Silt } \\
\text { (g) }\end{array}$ \\
\hline \multirow{5}{*}{$\begin{array}{l}\text { Substitute } \\
\text { for fly ash }\end{array}$} & F1 & 130 & 304 & 100 & 680 & 460 & 76 \\
\hline & F2 & 130 & 228 & 100 & 680 & 460 & 152 \\
\hline & F3 & 130 & 152 & 100 & 680 & 460 & 228 \\
\hline & F4 & 130 & 76 & 100 & 680 & 460 & 304 \\
\hline & F5 & 130 & 0 & 100 & 680 & 460 & 380 \\
\hline \multirow{5}{*}{$\begin{array}{l}\text { Substitute } \\
\text { for } \\
\text { bentonite }\end{array}$} & B1 & 130 & 380 & 80 & 680 & 460 & 20 \\
\hline & B2 & 130 & 380 & 60 & 680 & 460 & 40 \\
\hline & B3 & 130 & 380 & 40 & 680 & 460 & 60 \\
\hline & B4 & 130 & 380 & 20 & 680 & 460 & 80 \\
\hline & B5 & 130 & 380 & 0 & 680 & 460 & 100 \\
\hline \multirow{5}{*}{$\begin{array}{l}\text { Substitute } \\
\text { for sand }\end{array}$} & S1 & 130 & 380 & 100 & 544 & 460 & 136 \\
\hline & $\mathrm{S} 2$ & 130 & 380 & 100 & 408 & 460 & 272 \\
\hline & S3 & 130 & 380 & 100 & 272 & 460 & 408 \\
\hline & $\mathrm{S} 4$ & 130 & 380 & 100 & 136 & 460 & 544 \\
\hline & S5 & 130 & 380 & 100 & 0 & 460 & 680 \\
\hline
\end{tabular}

The third part was to adjust the proportion of materials in order to satisfy the needs of grouting performance after the replaceable material was identified as sand from the experimental results of Table 3. The proportion of water was increased to improve the flowability and the cement:fly ash ratio was adjusted to improve the strength, as shown in Table 4. In this table, the symbol of 'AF' means adjusting the flowability, and the symbol of 'AFS' means adjusting the strength on the basis of adjusting the flowability. The number from 1 to 4 means different degrees of adjustment measures, which change with equal gradient.

Table 4. Experimental schemes of adjusting the grouting performance.

\begin{tabular}{ccccccc}
\hline Type & Term of Mix & Cement (g) & Fly Ash (g) & Bentonite (g) & Clayey Silt (g) & Water (g) \\
\hline \multirow{3}{*}{ Adjust } & AF1 & 130 & 380 & 100 & 680 & 560 \\
flowability & AF2 & 130 & 380 & 100 & 680 & 610 \\
& AF3 & 130 & 380 & 100 & 680 & 660 \\
& AF4 & 130 & 380 & 100 & 680 & 710 \\
\hline \multirow{3}{*}{ Adjust } & AFS1 & 180 & 330 & 100 & 680 & 660 \\
strength & AFS2 & 230 & 280 & 100 & 680 & 660 \\
& AFS3 & 280 & 230 & 100 & 680 & 660 \\
& AFS4 & 330 & 180 & 100 & 680 & 660 \\
\hline
\end{tabular}

\section{Results and Discussion}

\subsection{Flowability of Grout Mixes}

The flowability parameters of traditional grout mixes changed over time are plotted in Figure 4. The figures of flowability present three kinds of data simultaneously in this paper. The first vertical axis shows consistency, the second vertical axis shows slump diameter and the annotation in the 
diagram shows grout-flow cone efflux time. It can be seen that the flowability from $\mathrm{T} 1$ to $\mathrm{T} 4$ has a decreasing tendency in the terms of consistency, slump diameter and grout-flow cone efflux time, which is caused by the decreasing water content in grout mixes. The water:powder ratio is an important factor associated with flowability, which decreases with decreasing water:powder ratio [41]. From the flowability results of $\mathrm{T} 1$ to $\mathrm{T} 4$, the mass of powder remained unchanged, the water:powder ratio decreased with the decreasing water mass, which caused the decreasing of flowability. Consistency and slump diameter had a similar variation trend; both were decreasing from $\mathrm{T} 1$ to $\mathrm{T} 4$ and decreased over time. Grout-flow cone efflux time got longer from $16.6 \mathrm{~s}$ to ' $\infty$ ' (' $\infty$ 'means the grout mix in the obconical funnel outflows incompletely or cannot flow). Both T1 and T2 had good performance in flowability according to the results of grout-flow efflux time. Thus, the flowability of T2 can be used as critical index to evaluate the performance of grout mixes.

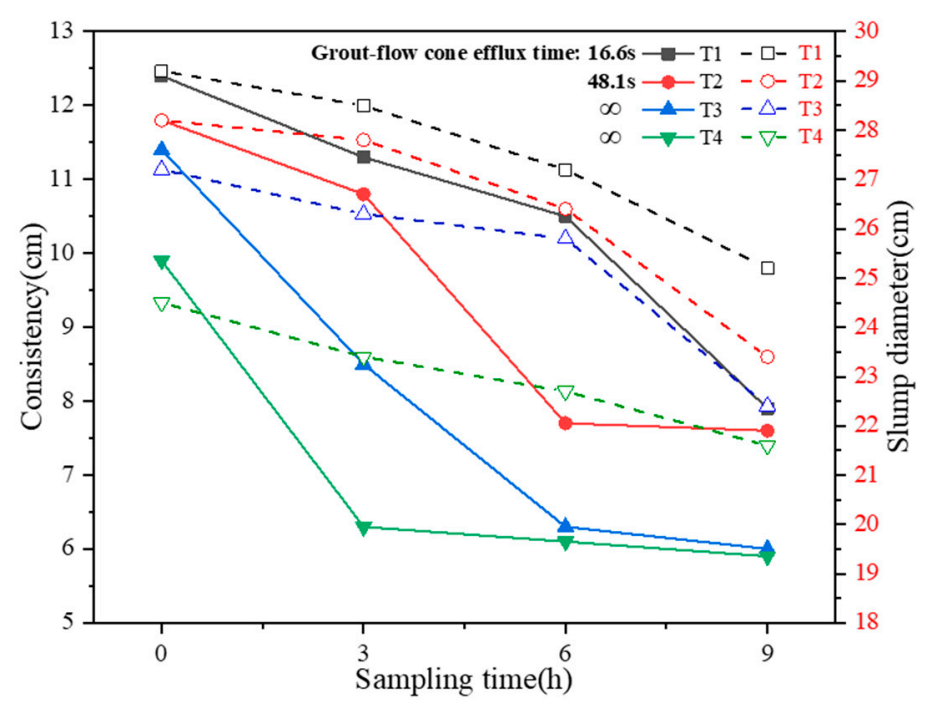

Figure 4. Flowability of traditional grout mixes.

From these experimental results combined with construction experience, the flowability of grout mixes needs to meet the following three requirements: (i) the consistency is greater than $11 \mathrm{~cm} \mathrm{in} 0 \mathrm{~h}$ and greater than $7 \mathrm{~cm}$ in $9 \mathrm{~h}$; (ii) the slump diameter is greater than $27 \mathrm{~cm}$ in $0 \mathrm{~h}$ and greater than $22 \mathrm{~cm}$ in $9 \mathrm{~h}$; (iii) the grout-flow cone efflux time is less than 60 seconds.

Figure 5 shows the flowability of the grout mixes when the clayey silt was reused as substitute for traditional raw materials. Flowability of $\mathrm{T} 2$ was used as a reference index as later schemes were based on it. From the flowability of clayey silt reused as substitute for fly ash (Figure 5a), grout-flow efflux time of F1 to F5 decreased from $32.1 \mathrm{~s}$ to $20.6 \mathrm{~s}$, which was smaller than $48.1 \mathrm{~s}$. Meanwhile both consistency $(0 \mathrm{~h})$ and slump diameter $(0 \mathrm{~h})$ were greater than T2. All these indicated that the initial flowability performed better when clayey silt was reused as a substitute for fly ash, but the flowability loss became more serious. The consistency ( $9 \mathrm{~h}$ ) of F1 to F5 distributed from $19.8 \mathrm{~cm}$ to $22.7 \mathrm{~cm}$, and the slump diameter $(9 \mathrm{~h})$ distributed from $5.8 \mathrm{~cm}$ to $7.4 \mathrm{~cm}$, which were lower than T2 and could not meet the requirements of flowability. The severe loss of flowability after clayey silt replaced fly ash was caused by the reduction of the ball bearing effect, which makes the particles roll like ball bearings to reduce the inter-particle friction [42]. It is apparent from the results that compared with fly ash, the clayey silt had less contribution to the ball bearing effect. 


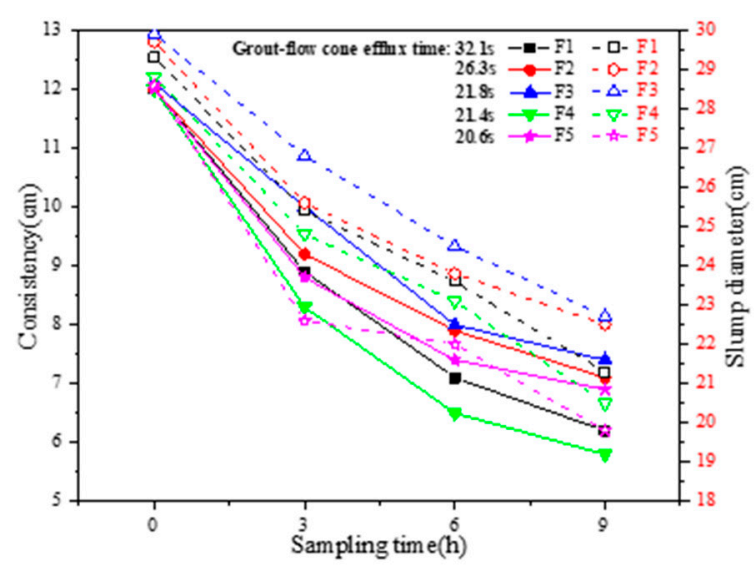

(a)

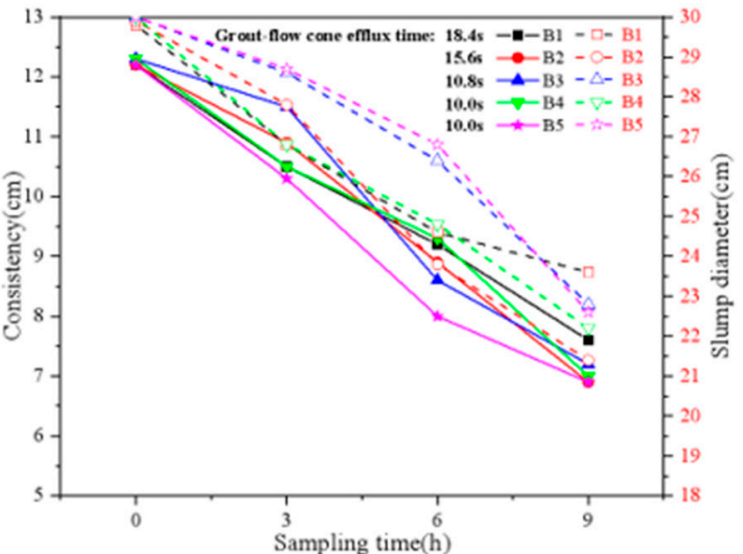

(b)

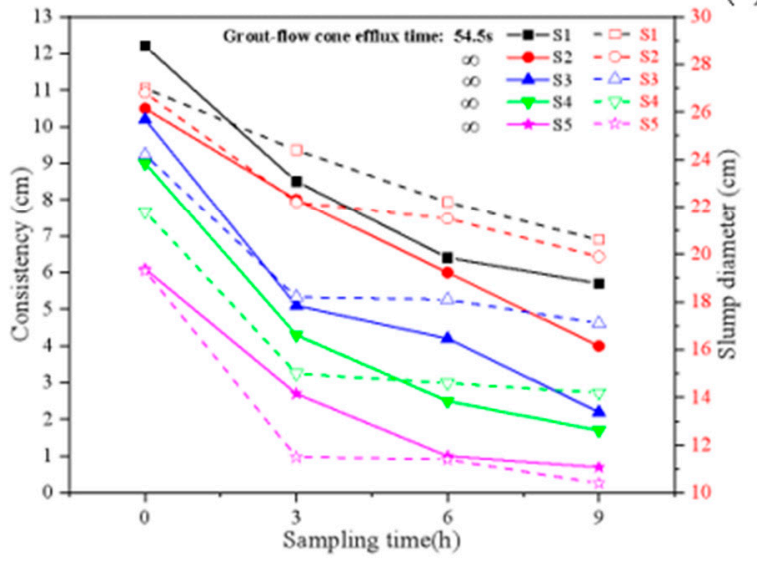

(c)

Figure 5. Flowability of grout mix when clayey silt was reused in traditional materials. (a) Substitute for fly ash, (b) substitute for bentonite, (c) substitute for sand.

As shown in Figure 5b, for the grout mixes when clayey silt was reused as substitute for bentonite, the grout-flow efflux time of B1 to B5 decreased from $18.4 \mathrm{~s}$ to $10.0 \mathrm{~s}$, which was very close to approaching the limit of mortar. Consistency $(0 \mathrm{~h})$ and slump diameter $(0 \mathrm{~h})$ were all higher than $\mathrm{T} 2$, which indicated the initial flowability was better than T2. However, the flowability loss had the opposite conclusion from the perspective of slump diameter and consistency. The test results of consistency showed that flowability losses after replacement were less compared with $\mathrm{T} 2$, while the results of slump diameter showed an opposite conclusion. This indicates that the results of consistency and slump diameter may be influenced by different factors. The consistency mainly depends on the concentration of grout mixes, which is influenced by the amount of water. Clayey silt reused as substitute for bentonite increased the water content of the grout mix, because the content of bentonite decreased, thus a lot of water could not be absorbed. The friction of falling cone decreased with the increasing of water content; thus, the consistency tended to be bigger than T2. The slump diameter was mainly affected by the shape of particles. The particles of bentonite are rounded and smooth while the particles of clayey silt are angular and rough [43]. This makes the grout mixes harder to spread under the throb of the machine and causes the slump diameter to tend to be smaller than T2. In fact, the results of consistency and slump diameter were influenced by many factors such as the formation of material strength, water content and shape of particles. The replacement of bentonite with clayey silt changed many factors, making it difficult to summarize the regularity of fluidity loss from B1 to B5 with the increasing proportion of clayey silt to bentonite. All results showed that the replacement of bentonite with clayey silt did not affect the satisfaction of flowability requirements. 
It is apparent that the flowability of S1 to S5 got worse than T2 from the flowability test results, as shown in Figure 5c. Mehdipour et al. [44] established a connection between particle size distribution and flowability. The particle size of clayey silt was smaller than sand from the particle size distribution analysis in Figure 2, which means the clayey silt had more specific area than sand, and this was the reason for more severe flowability loss after replacement. In addition, the higher water absorbing capacity of clayey silt than sand also caused the further flowability loss of grout mix. Only in the mix proportion of S1 could the grout mix flow out from the funnel. Both consistency and slump diameter decreased with the increasing proportion of clayey silt to sand. None of the schemes from B1 to B5 could meet the requirements of flowability.

Figure 6 shows the flowability after adjusting the mix proportion of materials on the basis of replacing sand with clayey silt totally. The flowability was significantly improved with the increase of water addition due to the increase of the water:powder ratio, as Figure 6a shows. The grout-flow cone efflux time of AF1 to AF4 decreased from ' $\omega$ ' to $12.1 \mathrm{~s}$. The consistency $(0 \mathrm{~h})$ increased from $6.5 \mathrm{~cm}$ to $12.3 \mathrm{~cm}$, and the consistency $(9 \mathrm{~h})$ increased from $5.9 \mathrm{~cm}$ to $10.0 \mathrm{~cm}$. The slump diameter $(0 \mathrm{~h})$ increased from $22.7 \mathrm{~cm}$ to $29.2 \mathrm{~cm}$, and the slump diameter $(9 \mathrm{~h})$ increased from $21.2 \mathrm{~cm}$ to $26.3 \mathrm{~cm}$. Both AF3 and AF4 could meet the requirements of flowability.

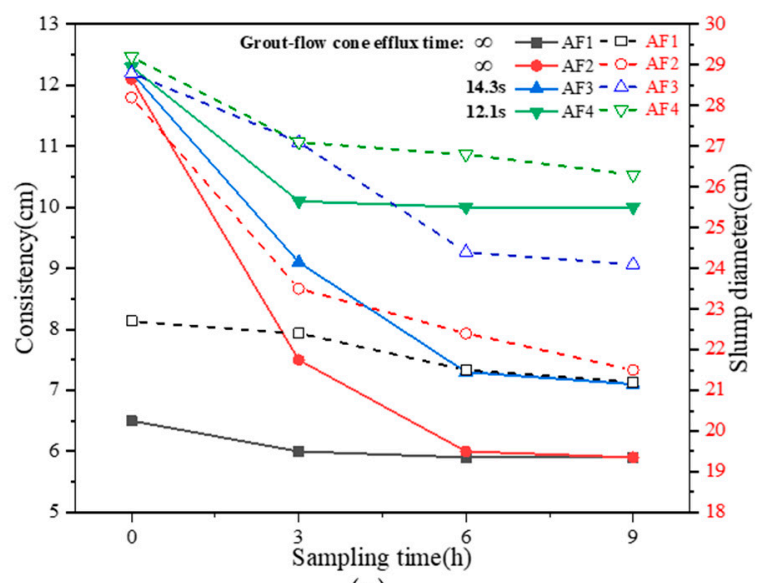

(a)

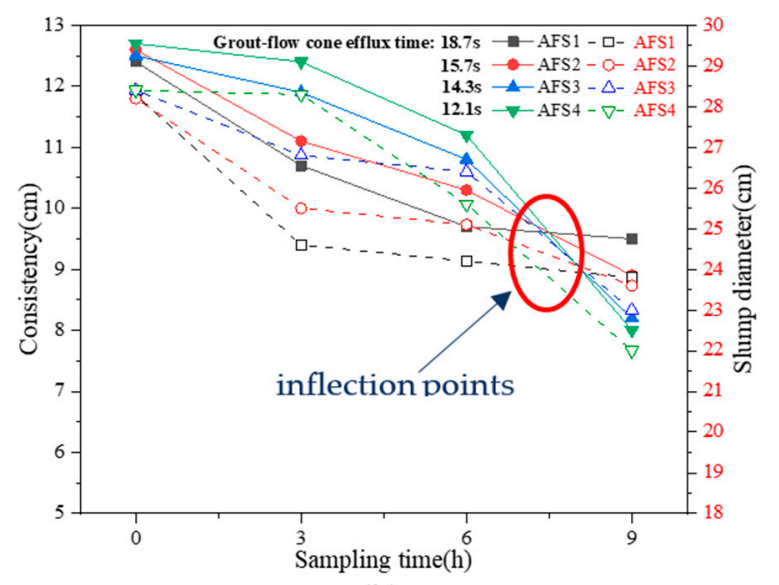

(b)

Figure 6. Flowability after adjusting the mix proportion of materials. (a) Adjusting the proportion of water, (b) adjusting the cement-fly ash ratio.

Figure $6 \mathrm{~b}$ shows the flowability of adjusting the cement:fly ash ratio on the basis of AF3. The influence of flowability after fly ash replacing cement has been studied by some researchers $[45,46]$, but these researchers only focused on the initial flowability; the flowability loss with time after adjusting the cement:fly ash ratio was not clear. From the experimental results after increasing the cement:fly ash ratio, the grout-flow cone efflux time of AFS1 to AFS4 decreased from $18.7 \mathrm{~s}$ to $12.1 \mathrm{~s}$; both consistency and slump diameter were improved compared with AF3. These four mix proportions (AFS1-AFS4) could all meet the requirements of flowability. The consistency and slump diameter had a decreasing tendency in 6 hours but an increasing tendency after 6 hours with the increased ratio of cement to fly ash from AFS1 to AFS4. The order of consistency and slump diameter at 9 hours from highest to lowest was AFS1 to AFS4. A possible explanation is that both cement and fly ash are binding material, but the rules of strength formation are different. During the curing time after materials were mixed, the fly ash reacted faster and played a bigger role at the first 6 hours, then the cement played a bigger role the rest of the time. The increasing proportion of cement to fly ash from AFS1 to AFS4 caused a reversal of flowability during the curing time, as the circled inflection points show in Figure $6 \mathrm{~b}$. 


\subsection{Bleeding Rate and Volume Shrinkage Rate of Grout Mixes}

Table 5 shows the results of bleeding rate and volume shrinkage rate of all schemes. A majority of the bleeding rates and volume shrinkage rates were under $5 \%$ according to the results of traditional grout mixes (T1-T4). Combining with construction experience, taking $5 \%$ as the upper limit of bleeding rate and volume shrinkage rate was reasonable in this paper.

Table 5. Results of bleeding rate and volume shrinkage rate test.

\begin{tabular}{ccccccccccc}
\hline \multirow{2}{*}{$\begin{array}{c}\text { Type of } \\
\text { Grout Mix }\end{array}$} & \multicolumn{4}{c}{ Bleeding Rate (\%) } & \multicolumn{5}{c}{ Volume Shrinkage Rate (\%) } \\
\cline { 2 - 11 } & $\mathbf{1}$ & $\mathbf{2}$ & $\mathbf{3}$ & $\mathbf{4}$ & $\mathbf{5}$ & $\mathbf{1}$ & $\mathbf{2}$ & $\mathbf{3}$ & $\mathbf{4}$ & $\mathbf{5}$ \\
\hline T & 5.3 & 4.0 & 2.3 & 1.4 & - & 4.4 & 3.3 & 2.2 & 1.9 & - \\
F & 4.4 & 2.8 & 2.4 & 2.2 & 1.9 & 3.3 & 2.7 & 3.0 & 2.5 & 3.1 \\
B & 9.1 & 12.4 & 13.5 & 14.9 & 16.0 & 2.5 & 2.7 & 3.4 & 5.8 & 7.2 \\
S & 2.2 & 1.3 & 0.2 & 0 & 0 & 2.8 & 2.7 & 2.5 & 2.4 & 2.3 \\
AF & 0.4 & 1.3 & 1.9 & 3.3 & - & 1.5 & 2.8 & 4.6 & 6.8 & - \\
AFS & 1.8 & 1.7 & 1.6 & 1.6 & - & 4.4 & 4.2 & 4.5 & 4.1 & - \\
\hline
\end{tabular}

It can be concluded from former research that the stability parameters, consisting of bleeding rates and volume shrinkage rates, were mainly influenced by the initial water content of grouts after the mixing of materials $[47,48]$. It is apparent that bleeding rates and volume shrinkage rates would increase with the increased amount of water from the results of T1-T4 and AF1-AF4. Bleeding rates decreased from $4.4 \%$ to $1.9 \%$ when clayey silt was reused as a substitute for fly ash from $20 \%$ to $100 \%$, while volume shrinkage rates were all around $3 \%$ and had no significant changes. The replacement of clayey silt for bentonite (B1-B5) made the bleeding rates increase from $9.1 \%$ to $16.0 \%$ and the volume shrinkage rates increase from $2.5 \%$ to $7.2 \%$, where most of them exceeded the upper limit of $5 \%$. Both bleeding rates and volume shrinkage rates decreased when clayey silt was reused as a substitute for sand. The adjustment of the cement:fly ash ratio did not influence the bleeding rates and volume shrinkage rates, as results of AFS1 to AFS4 showed. The reason for this might be because they are both binding materials, have similar particle size and consume approximate amounts of water in the mixing and reaction phases. Almost all mix proportions could meet the requirements of bleeding rate and volume shrinkage rate except for B1 to B5, which indicated that bentonite can absorb large amounts of water and plays an important role in the stability of grout mixes. Bentonite is irreplaceable from the view of stability in grout mixes.

\subsection{Final Setting Time and UCS of Grout Mixes}

Both the final setting time and the UCS (unconfined compressive strength) can be used to express the process of strength formation. The final setting time reflects short-term strength within 24 hours, while the UCS reflects long-term strength after 24 hours. Figures 7-9 show the processes of penetration resistance with increasing time, which had similar change rules with flowability, as Figures 4-6 show. For example, the growth of penetration resistance had no obvious correlation with the increasing substitution ratio of clayey silt to fly ash or bentonite within 9 hours, as shown in Figure 8a,b, which had similar rules to those in Figure $5 \mathrm{a}, \mathrm{b}$. The inflection points of the strength formation curve appeared about 6 hours later after mixing, as shown in Figure 9b, which were consistent with the previous explanation about the phenomenon that flowability starts to reverse after 6 hours, as Figure $6 \mathrm{~b}$ shows. 


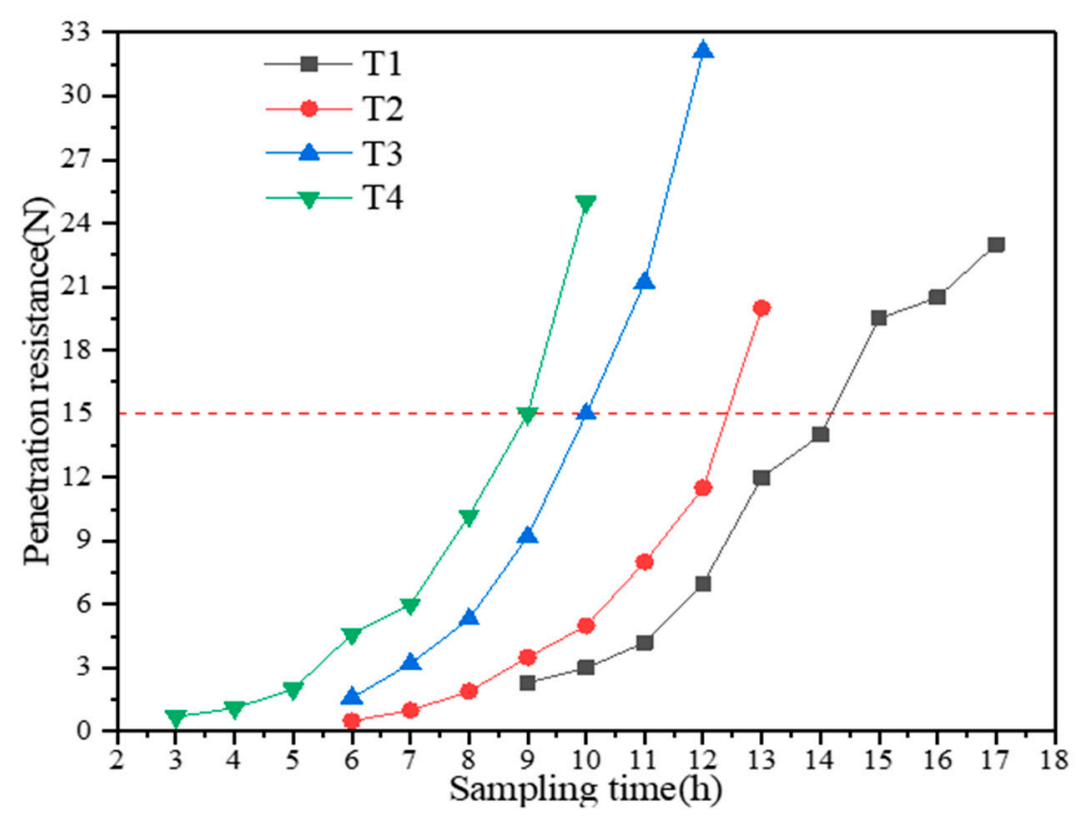

Figure 7. Penetration resistance of traditional grout mixes during curing time.

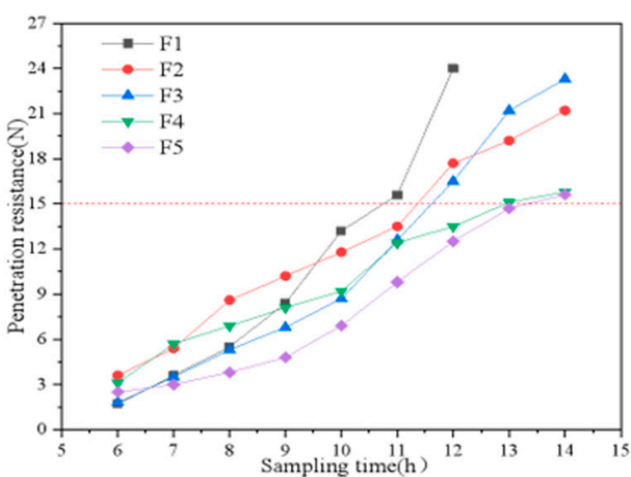

(a)

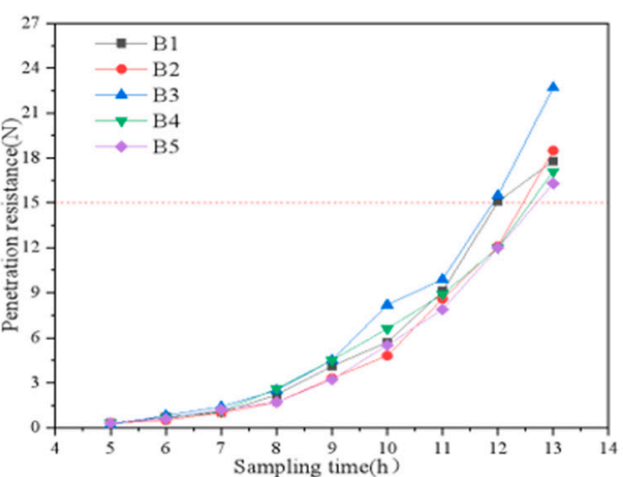

(b)

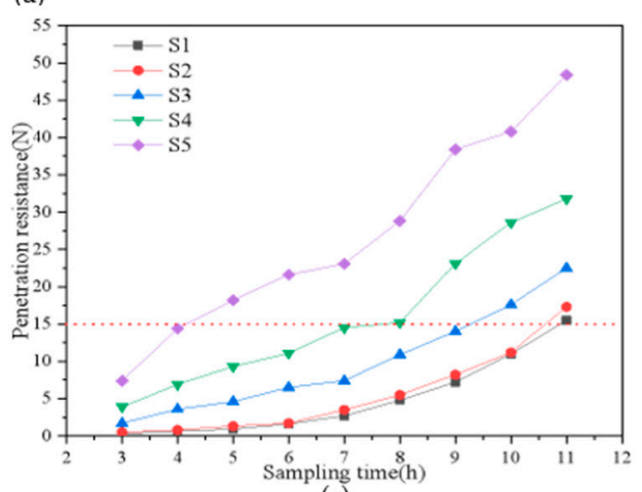

(c)

Figure 8. Penetration resistance of grout mix during curing time when clayey silt was reused in traditional materials. (a) Substitute for fly ash, (b) substitute for bentonite, (c) substitute for sand. 


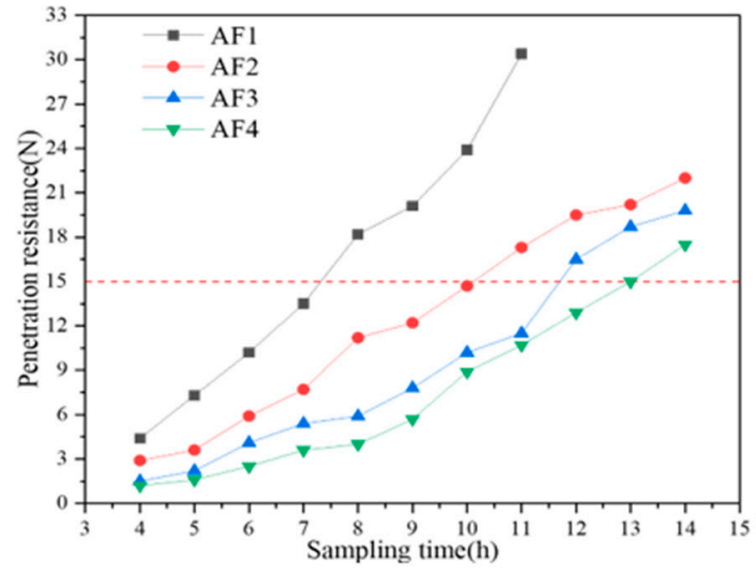

(a)

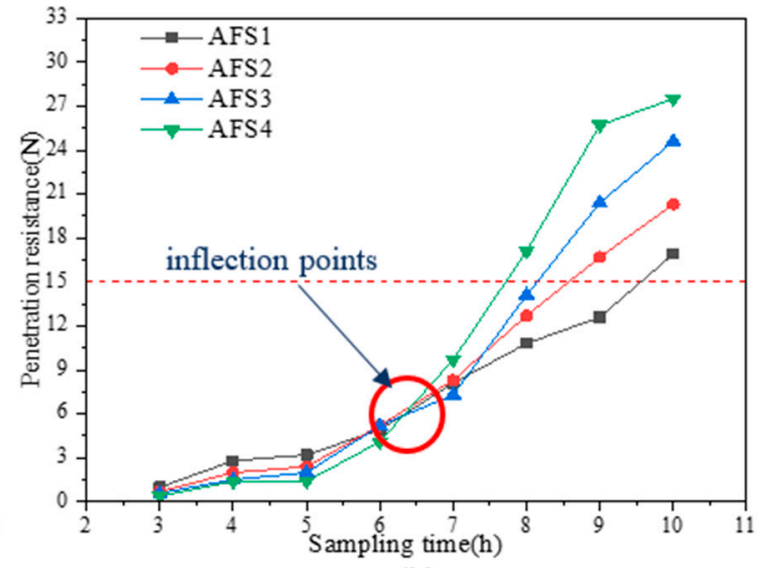

(b)

Figure 9. Penetration resistance after adjusting the ratio of materials during curing time. (a) Adjusting the proportion of water, (b) adjusting the ratio of cement and fly ash.

The final setting times of grout mixes when penetration resistance reached $15 \mathrm{~N}$ are recorded in Table 6. The final setting time of traditional grout mixes were distributed from $9 \mathrm{~h}$ to $14.2 \mathrm{~h}$ from the test results of $\mathrm{T} 1$ to $\mathrm{T} 4$. Considering the average time from producing grout mixes in mixing station and conveying it to the gap between the segment lining and soil, $7 \mathrm{~h}$ to $14 \mathrm{~h}$ was a reasonable range of final setting time. The requirements of UCS were determined from the results of T2; $0.2 \mathrm{Ma}, 1.0 \mathrm{MPa}$ and $2.5 \mathrm{MPa}$ were the minimum strength value in 1 day, 7 days and 28 days, respectively.

Table 6. Final setting time and UCS of grout mixes.

\begin{tabular}{|c|c|c|c|c|c|c|c|c|c|c|}
\hline \multirow{2}{*}{ Type } & \multicolumn{5}{|c|}{ Final setting time (h) } & \multicolumn{5}{|c|}{ UCS (MPa) of $1 \mathrm{~d}$} \\
\hline & 1 & 2 & 3 & 4 & 5 & 1 & 2 & 3 & 4 & 5 \\
\hline $\mathrm{T}$ & 14.2 & 12.4 & 10.0 & 9.0 & - & 0.23 & 0.26 & 0.42 & 0.50 & - \\
\hline $\mathrm{F}$ & 10.7 & 11.3 & 11.6 & 12.9 & 13.4 & 0.24 & 0.22 & 0.16 & 0.15 & 0.13 \\
\hline B & 12.0 & 12.5 & 11.9 & 12.6 & 12.7 & 0.13 & 0.17 & 0.22 & 0.24 & 0.20 \\
\hline$S$ & 10.9 & 10.6 & 9.3 & 7.7 & 4.2 & 0.29 & 0.22 & 0.20 & 0.32 & 0.31 \\
\hline $\mathrm{AF}$ & 7.3 & 10.1 & 11.7 & 13.0 & - & 0.20 & 0.17 & 0.11 & 0.08 & - \\
\hline AFS & 9.5 & 8.5 & 8.1 & 7.7 & - & 0.09 & 0.14 & 0.20 & 0.26 & - \\
\hline \multirow{2}{*}{ Type } & \multicolumn{5}{|c|}{$\mathrm{UCS}(\mathrm{MPa})$ of $7 \mathrm{~d}$} & \multicolumn{5}{|c|}{ UCS (MPa) of $28 \mathrm{~d}$} \\
\hline & 1 & 2 & 3 & 4 & 5 & 1 & 2 & 3 & 4 & 5 \\
\hline $\mathrm{T}$ & 1.03 & 1.17 & 1.58 & 1.89 & - & 2.61 & 2.73 & 3.54 & 4.85 & - \\
\hline $\mathrm{F}$ & 1.03 & 0.91 & 0.67 & 0.64 & 0.61 & 2.13 & 1.93 & 1.38 & 1.21 & 1.06 \\
\hline B & 0.99 & 1.07 & 1.40 & 1.40 & 1.32 & 1.78 & 2.18 & 3.44 & 2.89 & 2.43 \\
\hline$S$ & 1.07 & 1.27 & 1.18 & 1.38 & 1.29 & 3.09 & 3.64 & 3.83 & 3.69 & 3.50 \\
\hline $\mathrm{AF}$ & 0.88 & 0.69 & 0.55 & 0.47 & - & 1.41 & 1.37 & 1.25 & 0.75 & - \\
\hline AFS & 0.60 & 0.90 & 1.46 & 2.96 & - & 1.17 & 2.03 & 2.96 & 3.70 & - \\
\hline
\end{tabular}

It can be concluded from Table 6 that almost all types of grout mixes can meet the demand of final setting time except for S5, which is too short (4.2 h). The UCS is too small to meet the strength requirements when clayey silt is reused as a substitute for fly ash(F1-F5). With the increasing proportion of clayey silt reused as substitute for bentonite(B1-B5), the UCS goes up first but then it goes down. It is theorized that clayey silt can provide more cohesion than bentonite in grout mixes, but with the reduction of bentonite, grout mixes cannot hold steady and internal splits occur, causing the loss of strength. The replacement of clayey silt for sand(S1-S5) increased the UCS of specimens, which could all meet the strength requirements. It can be concluded from the UCS of AF1 to AF4 that adding the proportion of water on the basis of S5 reduced the strength of mixes and could not meet the strength 
requirements. The strength of specimens was greatly improved by increasing the ratio of cement to fly ash from AFS1 to AFS4. Both AFS3 and AFS4 could meet the requirements of UCS.

\subsection{Pore Structure Analysis}

The specimen of T2 and S5 are two typical specimens in this research. Further study of these two specimens were needed for a better understanding of the differences before and after the clayey silt replacing sand. The pore structure features, XRD tests and SEM tests were performed in this research.

The pore structure features were analyzed because they were associated with the strength of concrete or mortar $[49,50]$. For obtaining the pictures of planar sections and more intuitive analysis of pore structure characteristics, the specimens of T2 and S5 were split in half and polished to obtain smooth surfaces, as shown in Figures 10a and 11a. For clear observation of the pore structure features, the surface of the section was painted with black ink, and then pores were filled with white nano- $\mathrm{CaCO}_{3}$ powders, as shown in Figures $10 \mathrm{~b}$ and $11 \mathrm{~b}$. Then, the images of treated sections were executed for binary conversion in software Image-Pro Plus 6.0, as shown in Figures 10c and 11c. By counting the number of black and white pixels in Image-Pro Plus 6.0, the porosity of the section could be calculated, which was $39.1 \%$ for T2 and 5.1\% for S5. Besides, from the images of Figures 10a and 11a, it can be concluded that the specimen S5 had a smoother surface than T2, which was caused by higher strength.
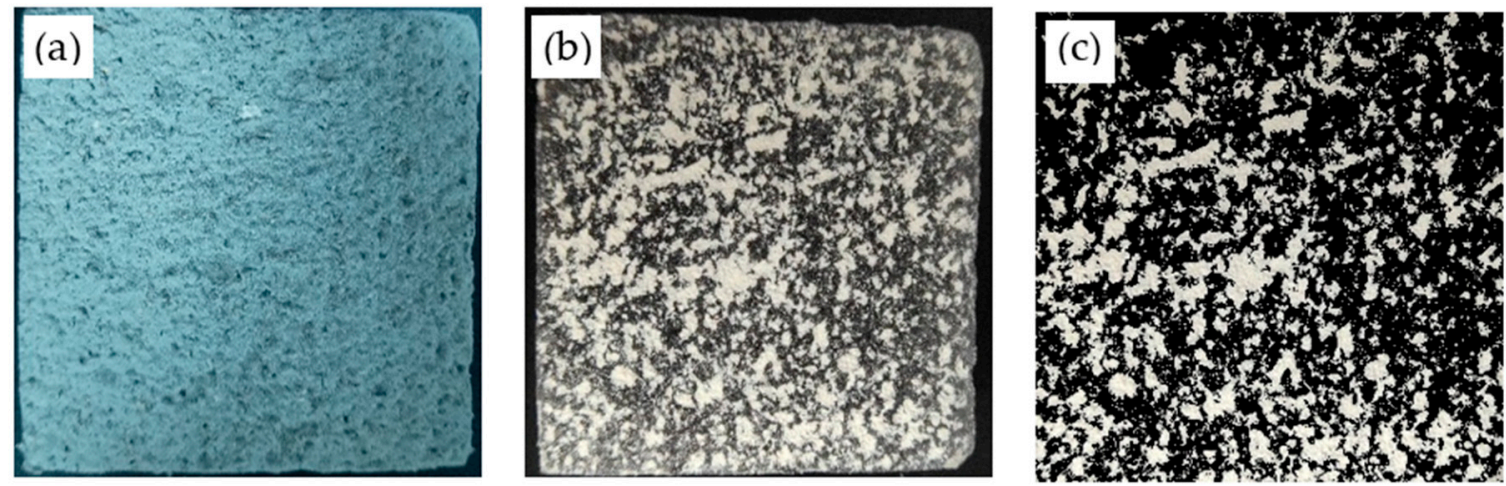

Figure 10. Images of sections of specimen T2. (a) Image of initial section, (b) image of treated section, (c) image after binary conversion.
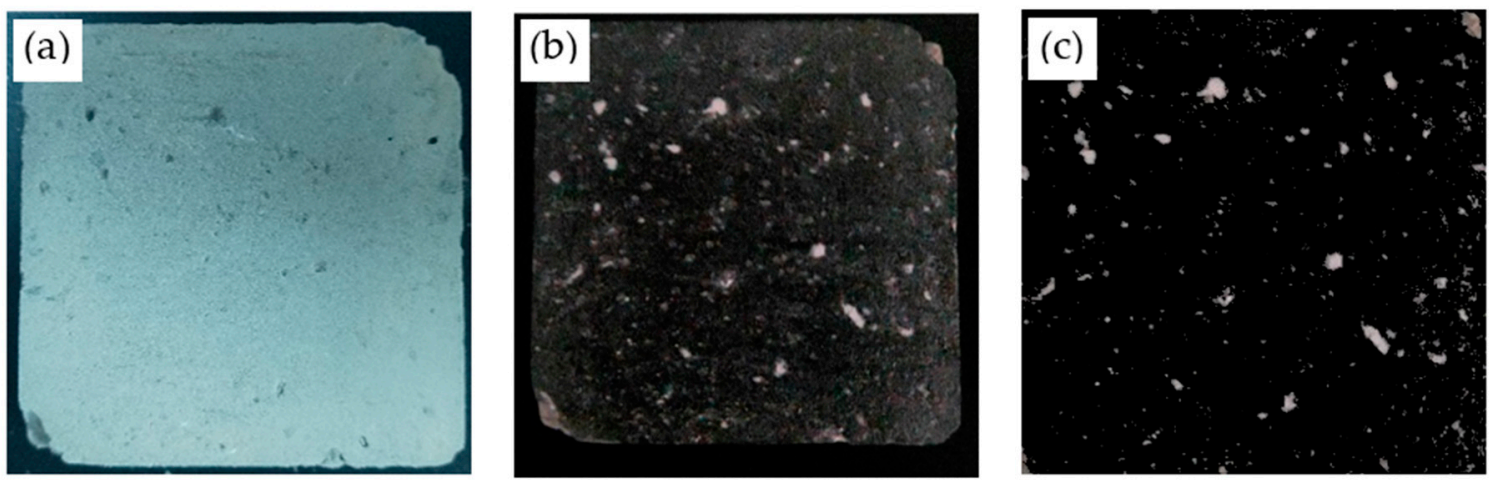

Figure 11. Images of sections of specimen S5. (a) Image of initial section, (b) image of treated section, (c) image after binary conversion.

\subsection{XRD Analysis}

The hydration products of two typical specimens (T2 and S5) were analyzed by X-ray diffraction combined with the software MDI Jade 6.0 in order to better understand the changes of grout mix after clayey silt was reused as substitute for sand. As shown in Figures 12 and $13, \mathrm{CaCO}_{3}, \mathrm{SiO}_{2}, \mathrm{Aft}$ (ettringite), $\mathrm{C}-\mathrm{S}-\mathrm{H}$ and $\mathrm{Ca}(\mathrm{OH})_{2}$ were found in the stone body of grouts. Reaction products under the 
proportion of $\mathrm{T} 2$ and $\mathrm{S} 5$ were similar except for $\mathrm{SiO}_{2}$ during different curing times, which had certain extent effects on the strength [51]. The peaks of $\mathrm{SiO}_{2}$ were more obvious in specimen $\mathrm{S} 5$ than $\mathrm{T} 2$, which could be explained from the perspective of particle size. The aggregate was sand in T2 and clayey silt in S5. From the results of XRF, the content of $\mathrm{SiO}_{2}$ in sand and clayey silt was $69.11 \%$ and $65.35 \%$, respectively, which were close, but the particle size of clayey silt was smaller than sand. The particles of sand were easily covered by other materials due to the smaller specific area than clayey silt after being mixed with other materials, making it hard to be detected by the machine. It could be observed that the content of $\mathrm{C}-\mathrm{S}-\mathrm{H}$ gel increased while $\mathrm{Ca}(\mathrm{OH})_{2}$ decreased during curing time, which was due to the reaction of sodium silicate with $\mathrm{Ca}(\mathrm{OH})_{2}$ and formation of $\mathrm{C}-\mathrm{S}-\mathrm{H}$ gel, which was an important source of strength.

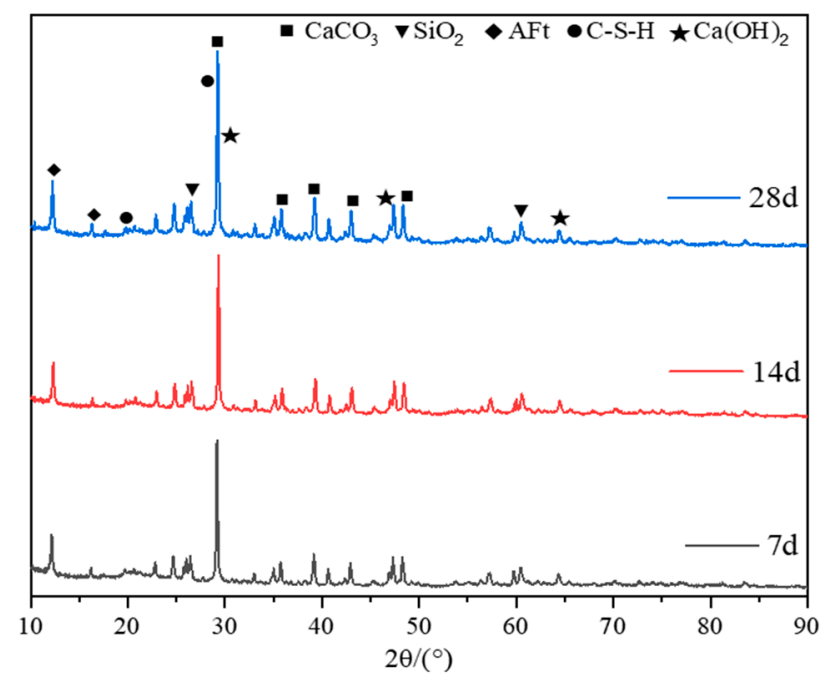

Figure 12. XRD spectra of specimen $\mathrm{T} 2$ at 7, 14 and 28 days.

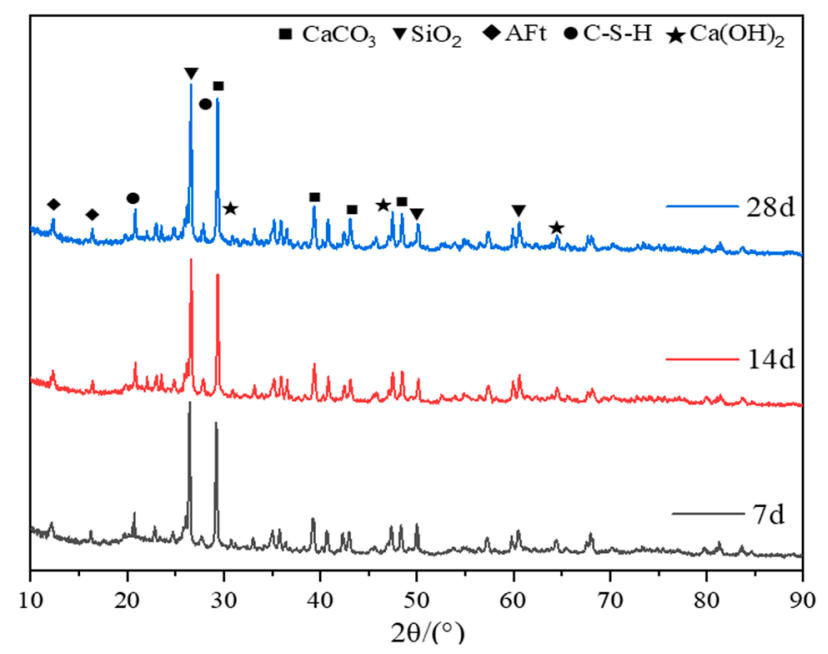

Figure 13. XRD spectra of specimen $S 5$ at 7, 14 and 28 days.

\subsection{SEM Analysis}

The microstructures of two typical specimens (T2 and S5) were invested by SEM. The results are shown in Figures 14 and 15. Each group has four photos from the scale of $500 \mu \mathrm{m}$ to $1 \mu \mathrm{m}$. It is clear from Figures $14 \mathrm{a}$ and $15 \mathrm{a}$ that many pores were formed during the molding process. The sand $\left(\mathrm{SiO}_{2}\right)$ had an angular outline and was large in size, as observed in Figure 14a. The surface of the specimen was rough, and no obvious composition could be observed except for the pore, as shown in Figure 15a, which corresponded to the size distribution of materials. According to Figure 15b, there were many 
irregular shaped structures, which had smaller sizes than FA. The test results of EDS indicated that the main element of those structure was $\mathrm{Si}$ and a little $\mathrm{Al}$, which were consistent with the components of clayey silt.
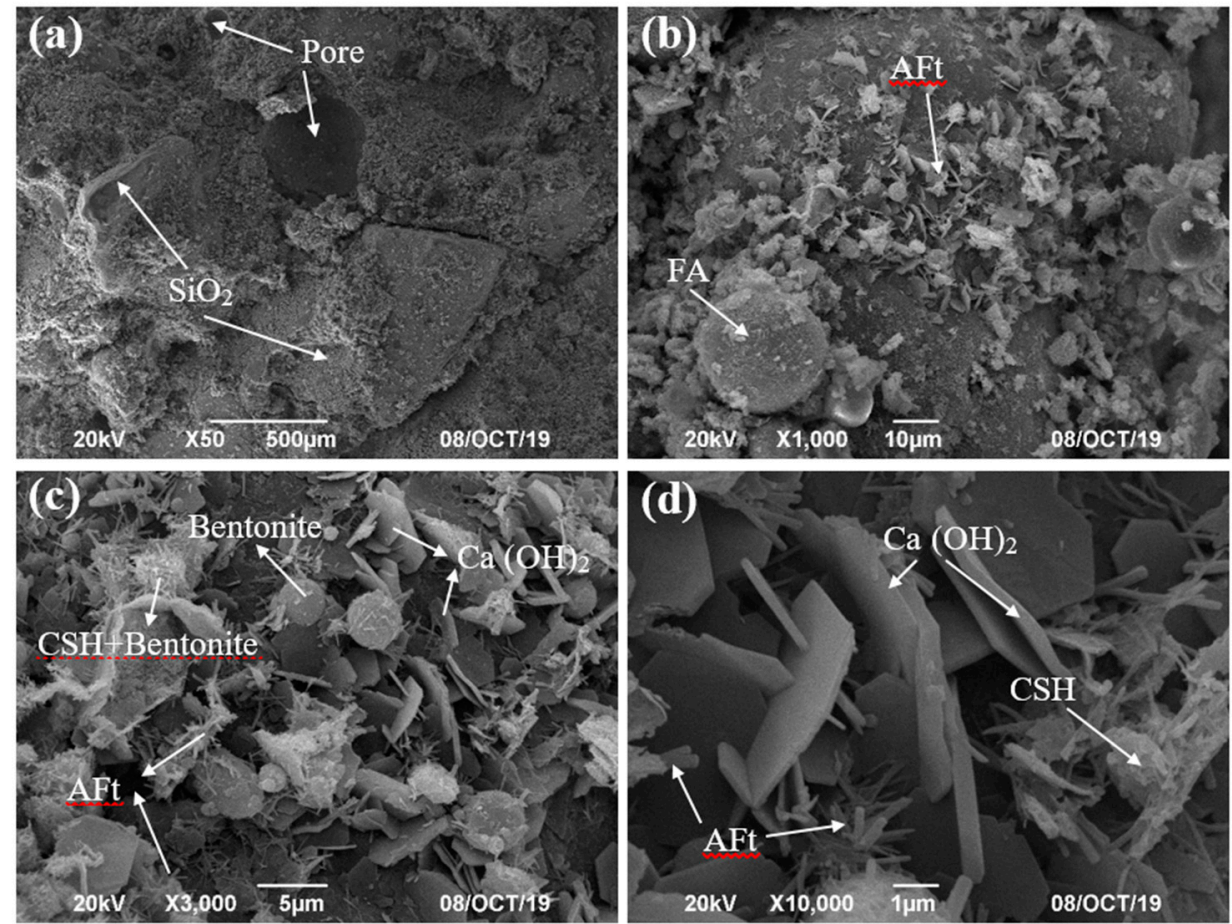

Figure 14. SEM photos of 28-day hardened grouts (T2): (a) $500 \mu \mathrm{m}$, (b) $10 \mu \mathrm{m}$, (c) $5 \mu \mathrm{m}$, (d) $1 \mu \mathrm{m}$.
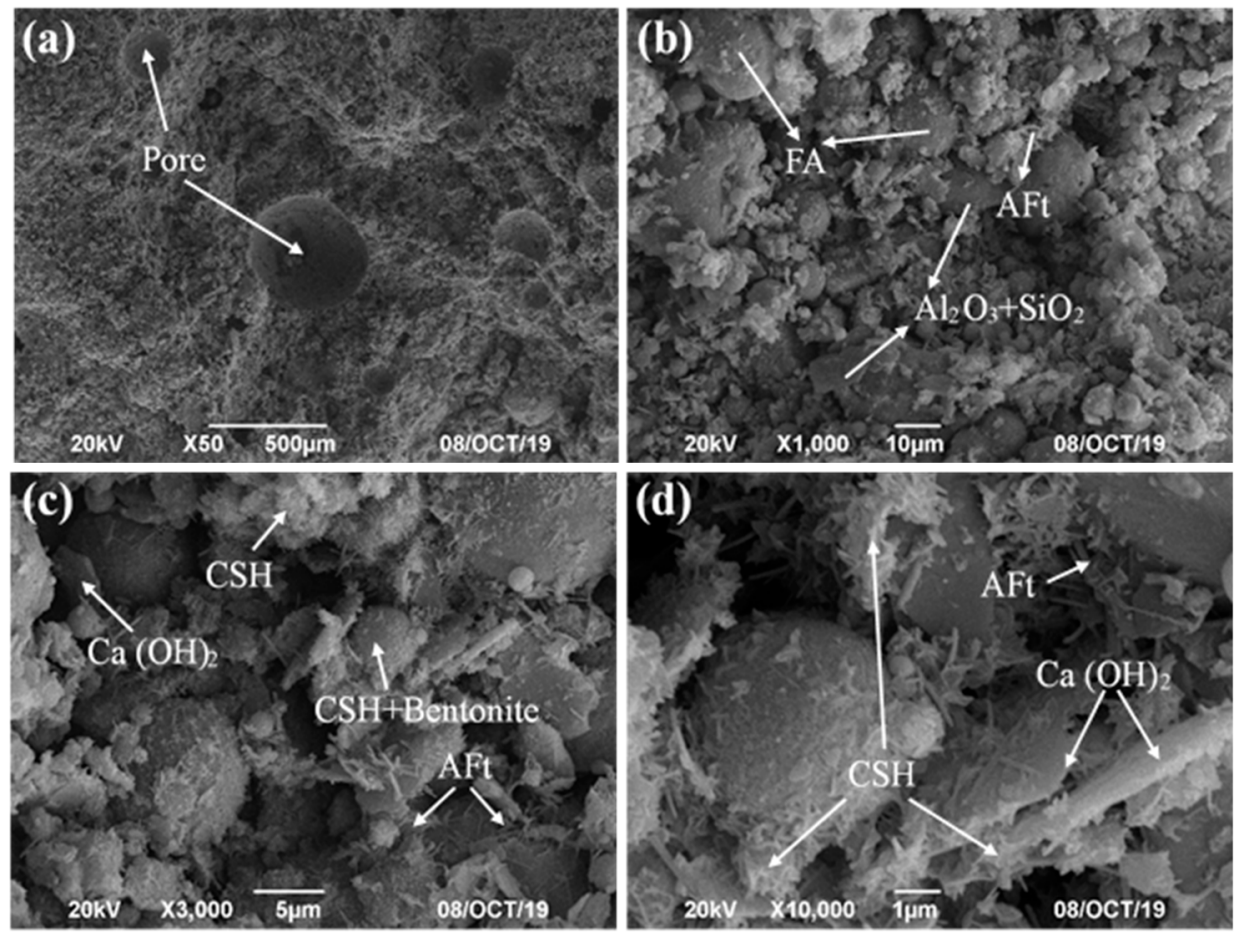

Figure 15. SEM photos of 28-day hardened grouts(S5) (a) $500 \mu \mathrm{m}$ (b) $10 \mu \mathrm{m}$ (c) $5 \mu \mathrm{m}$ (d) $1 \mu \mathrm{m}$.

It can be concluded that the hydration of S5 was more thorough than T2, as seen in Figure 14c, d and Figure $15 c$,d. The surface of $\mathrm{Ca}(\mathrm{OH})_{2}$ was clear and easy to be observed, as seen in Figure $14 \mathrm{c}, \mathrm{d}$, while 
$\mathrm{Ca}(\mathrm{OH})_{2}$ was covered by much $\mathrm{CSH}$ gel and difficult to be observed in Figure $15 \mathrm{c}, \mathrm{d}$. The consumption of $\mathrm{Ca}(\mathrm{OH})_{2}$ by chemical reaction caused a decrease of $\mathrm{Ca}(\mathrm{OH})_{2}$; meanwhile, smaller sized $\mathrm{SiO}_{2}$ had reactions with $\mathrm{Ca}(\mathrm{OH})_{2}$, producing many CSH gels covering the surface of $\mathrm{Ca}(\mathrm{OH})_{2}$ and FA. The SEM analysis indicated that grout mixes had more thorough hydration reaction due to the smaller particle size of aggregate after clayey silt was reused as substituted for sand.

\section{Conclusions}

Based on the demands of grout mixes in back-fill grouting, the clayey silt from shield excavation were prepared to be reused in cementitious grout mixes as a substitute for fly ash, bentonite and sand. The flowability, stability and strength of grout mixes were conducted as reference indicators to judge the practicability of the schemes and guided the adjustment of mixture proportion. The conclusions of results can be drawn as follows:

1. Four groups of traditional grouting mixes were tested after decreasing the proportion of water on the basis of referenced mix proportion from a construction site. The recommended requirements of grout performance parameters in this paper consisted of flowability, stability and strength and were determined by the test results of $\mathrm{T} 1$ to $\mathrm{T} 4$. Considering the balance of flowability and strength, T2 was used as the basic mix proportion of the subsequent tests, which was cement:fly ash:bentonite:sand:water $=130: 380: 100: 680: 460$.

2. The clayey silt was reused as a substitute for fly ash, bentonite and sand in back-fill grouts on the basis of their similar oxide composition and particle size. When clayey silt was reused to replace fly ash, the flowability loss was aggravated and the strength performed poorly, which was hard to reconcile by adjusting the mix proportion to meet all grouting requirements. When clayey silt was reused to replace bentonite, the stability, especial for bleeding rate, greatly surpassed the upper limit and it was hard to meet relevant requirements. When clayey silt was reused to substitute sand, the flowability was in sharp decline but the stability and strength were enhanced, which was feasible as a scheme of reutilization.

3. The proportion of materials was adjusted to meet the requirements of grout mixes on the basis of clayey silt substitution of sand totally (S5). After the exploration of increasing the proportion of water from AF1 to AF4 to improve flowability and increasing the cement:fly ash ratio from AFS1 to AFS4 to increase strength, a mix proportion that can meet all grouting requirements was determined, which was AFS3 (cement:fly ash:bentonite:clayey silt:water = 280:230:100:680:660). This utilization scheme of excavated clayey silt reused in back-fill grouts can reduce the disposal of excavated soils and cut the consumption of sands, which is environmentally friendly and sustainable.

4. In order to analyze the pore structure features, the specimens of T2 and S5 were split in half and treated by black inks and white nano- $\mathrm{CaCO}_{3}$; it was concluded that the section of $\mathrm{S} 5$ had smaller porosity and smoother surface than $\mathrm{T} 2$. In comparison with the hydration products and the microstructures of hardened grouts, the existence of $\mathrm{SiO}_{2}$ in $\mathrm{S} 5$ was easier to be detected than $\mathrm{T} 2$ in XRD analyses. It could be confirmed that the hydration degree of S5 was higher than T2 from the quantity of CSH gel in SEM photos. The replacement of sand for clayey silt would not change the types of product but would increase the hydration degree, which reflected the strength.

Author Contributions: Conceptualization: C.X. and H.-N.W.; Methodology: J.X. and X.K.; Validation: J.X.; Formal analysis: J.X. C.X. and H.W.; Investigation: J.X. and X.K.; Resources, C.X. and H.-N.W.; Writing-original draft preparation: J.X.; Writing-review and editing: H.-N.W. and X.K.; Project administration: H.-N.W. and C.X. All authors have read and agreed to the published version of the manuscript.

Funding: The research was funded by the National Natural Science Foundation of China (51938005) and the Tunnel Construction Project of China, Construction Fifth Engineering Division Corp., Ltd, (18430102002668).

Conflicts of Interest: The authors declare no conflict of interest. 


\section{References}

1. Shen, S.L.; Wu, H.N.; Cui, Y.J.; Yin, Z.Y. Long-term settlement behaviour of metro tunnels in the soft deposits of Shanghai. Tunn. Undergr. Space Technol. 2014, 40, 309-323. [CrossRef]

2. Liu, P.F.; Wang, S.Y.; Ge, L.; Thewes, M.; Yang, J.S.; Xia, Y.M. Changes of Atterberg limits and electrochemical behaviors of clays with dispersants as conditioning agents for EPB shield tunnelling. Tunn. Undergr. Space Technol. 2018, 73, 244-251. [CrossRef]

3. Wu, H.N.; Shen, S.L.; Yang, J.; Zhou, A.N. Soil-tunnel interaction modelling for shield tunnels considering shearing dislocation in longitudinal joints. Tunn. Undergr. Space Technol. 2018, 78, 168-177. [CrossRef]

4. Liu, J.; Song, J.; Zhang, Z.S.; Hu, N.Q. Influence of the Ground Displacement and Deformation of Soil around a Tunnel Caused by Shield Backfilled Grouting during Construction. J. Perform. Constr. Facil. 2016, 31, 04016117. [CrossRef]

5. Cui, Q.L.; Xu, Y.S.; Shen, S.L.; Yin, Z.Y.; Horpibulsuk, S. Field performance of concrete pipes during jacking in cemented sandy silt. Tunn. Undergr. Space Technol. 2015, 49, 336-344. [CrossRef]

6. Youn, B.-Y.; Breitenbücher, R. Influencing parameters of the grout mix on the properties of annular gap grouts in mechanized tunneling. Tunn. Undergr. Space Technol. 2014, 43, 290-299. [CrossRef]

7. Peila, D.; Luca, B.; Sebastiano, P. The behaviour of a two-component backfilling grout used in a tunnel-boring machine. Acta Geotech.Slov. 2011, 1, 5-15.

8. Zhang, P.; Chen, R.P.; Wu, H.N. Real-time analysis and regulation of EPB shield steering using Random Forest. Autom. Constr. 2019, 106, 102860. [CrossRef]

9. Meng, F.Y.; Chen, R.P.; Kang, X. Effects of tunneling-induced soil disturbance on the post-construction settlement in structured soft soils. Tunn. Undergr. Space Technol. 2018, 80, 53-63. [CrossRef]

10. Shah, R.; Arash, A.L.; Peila, D.; Todaro, C.; Luciani, A.; Schanz, T. Numerical Study on Backfilling the Tail Void Using a Two-Component Grout. J. Mater. Civ. Eng. 2018, 30, 1-9. [CrossRef]

11. Yang, C.; Shen, S.L.; Hou, D.W.; Liao, S.M.; Yuan, D.J. Material properties of the seal gasket for shield tunnels: A review. Constr. Build. Mater. 2018, 191, 877-890. [CrossRef]

12. Thewes, M.; Budach, C. Grouting of the annular gap in shield tunneling-an important factor for minimization of settlements and for production performance. In Proceedings of the ITA-AITES World Tunnel Congress, Budapest, Hungary, 23-29 May 2009.

13. FRNARC. Specification and Guidelines for the Use of Specialist Products for Mechanized Tunnelling(TBM) in Soft Ground and Hard Rock. 2005. Available online: http://www.efnarc.org/pdf/TBMGuidelinesApril05.pdf (accessed on 31 January 2020).

14. Pelizza, S.; Peila, D.; Borio, L.; Negro, E.; Schulkins, R.; Boscaro, A. Analysis of the Performance of Two Component Back-filling Grout in Tunnel Boring Machines Operating under Face Pressure. 2010. Available online: https://www.tunnelcanada.ca/members/documents/2010/WTC2010/pdf/fin00148.pdf (accessed on 31 January 2020).

15. Peila, D.; Chieregato, A.; Martinelli, D.; Oñate Salazar, C.; Shah, R.; Boscaro, A.; Negro, E.D.; Picchio, A. Long term behavior of two component back-fill grout mix used in full face mechanized tunneling. Geoing. Ambient. Mineraria 2015, 144, 57-63.

16. Sharghi, M.; Chakeri,H.; Afshin,H.; Ozcelik, Y. An Experimental Study of the Performance of Two-Component Backfilling Grout Used behind the Segmental Lining of a Tunnel-Boring Machine. J. Test. Eval. 2018, 46, 2083-2099. [CrossRef]

17. Bäppler, K. Development of a Two-Component Dynamic Grouting System for Tailskin Injected Backfilling of the Annular Gap for Segmental Concrete Lining in Shielded Tunnel Boring Machines. 2006. Available online: https://mountainscholar (accessed on 31 January 2020).

18. Neramitkornburi, A.; Horpibulsuk, S.; Shen, S.L.; Chinkulkijniwat, A.; Arulrajah, A.; Disfani, M.M. Durability against wetting-drying cycles of sustainable Lightweight Cellular Cemented construction material comprising clay and fly ash wastes. Constr. Build. Mater. 2015, 77, 41-49. [CrossRef]

19. Horpibulsuk, S.; Rachan, R.; Suddeepong, A. Assessment of strength development in blended cement admixed Bangkok clay. Constr. Build. Mater. 2011, 25, 1521-1531. [CrossRef]

20. Yi, Y.L.; Meles, D.; Nassiri, S.; Bayat, A. On the compressibility of tire-derived aggregate: Comparison of results from laboratory and field tests. Can. Geotech. J. 2015, 52, 442-458. [CrossRef] 
21. Yi, Y.L.; Zheng, X.; Liu, S.Y.; Al-Tabbaa, A. Comparison of reactive magnesia- and carbide slag-activated ground granulated blastfurnace slag and Portland cement for stabilisation of a natural soil. Appl. Clay Sci. 2015, 111, 21-26. [CrossRef]

22. Kang, X.; Kang, G.-C.; Chang, K.-T.; Ge, L. Chemically Stabilized Soft Clays for Road-Base Construction. J. Mater. Civ. Eng. 2014, 27, 04014199. [CrossRef]

23. Nambiar, E.K.K.; Ramamurthy, K. Influence of filler type on the properties of foam concrete. Cement Concr. Compos. 2006, 28, 475-480. [CrossRef]

24. Rashad, A.M. A preliminary study on the effect of fine aggregate replacement with metakaolin on strength and abrasion resistance of concrete. Constr. Build. Mater. 2013, 44, 487-495. [CrossRef]

25. Zhang, C.; Yang, J.S.; Ou, X.F.; Fu, J.Y.; Xie, Y.P.; Liang, X. Clay dosage and water/cement ratio of clay-cement grout for optimal engineering performance. Appl. Clay Sci. 2018, 163, 312-318. [CrossRef]

26. Zhong, X.C.; Jia, Z.; Liu, Q.W.; Han, Y.W. Reuse of excavated fine sand for back grouting of shield tunnelling. Rock Soil Mech. 2008, 29, 293-296.

27. Aboutabikh, M.; Soliman, A.M.; El Naggar, M.H. Properties of cementitious material incorporating treated oil sands drill cuttings waste. Constr. Build. Mater. 2016, 111, 751-757. [CrossRef]

28. Kassem, M.; Soliman, A.; El Naggar, H. Sustainable approach for recycling treated oil sand waste in concrete: Engineering properties and potential applications. J. Clean Prod. 2018, 204, 50-59. [CrossRef]

29. Shinde, S.; Naikwadi, S.; Shevde, N.; Ansari, F. Utilization of Ceramic Waste in Grout. Int. Res. J. Eng. Technol. 2019, 6, 129-132.

30. Zhou, S.H.; Li, X.; Ji, C.; Xiao, J.H. Back-fill grout experimental test for discharged soils reuse of the large-diameter size slurry shield tunnel. KSCE J. Civ. Eng. 2017, 21, 725-733. [CrossRef]

31. Çınar, M.; Karpuzcu, M.; Çanakcı, H. The measurement of fresh properties of cement-based grout containing waste marble powder. Measurement 2020, 150, 106833. [CrossRef]

32. Ouattara, D.; Belem, T.; Mbonimpa, M.; Yahia, A. Effect of superplasticizers on the consistency and unconfined compressive strength of cemented paste backfills. Constr. Build. Mater. 2018, 181, 59-72. [CrossRef]

33. Su, Y.; Feng, J.; Jin, P.; Qian, C. Influence of bacterial self-healing agent on early age performance of cement-based materials. Constr. Build. Mater. 2019, 218, 224-234. [CrossRef]

34. Domone, P. The Slump Flow Test for High-Workability Concrete. Cem. Concr. Res. 1998, 28, $177-182$. [CrossRef]

35. Roussel, N.; Le Roy, R. The Marsh cone: a test or a rheological apparatus? Cem. Concr. Res. 2005, 35, 823-830. [CrossRef]

36. Benaicha, M.; Jalbaud, O.; Hafidi Alaoui, A.; Burtschell, Y. Marsh cone coupled to a plexiglas horizontal channel: Rheological characterization of cement grout. Flow Meas. Instrum. 2015, 45, 126-134. [CrossRef]

37. Kang, X.; Kang, G.-C.; Ge, L. Modified Time of Setting Test for Fly Ash Paste and Fly Ash-Soil Mixtures. J. Mater. Civ. Eng. 2013, 25, 296-301. [CrossRef]

38. De Schutter, G.; Poppe, A.M. Quantification of the water demand of sand in mortar. Constr. Build. Mater. 2004, 18, 517-521. [CrossRef]

39. Wang, L.J.; Ai, H.M. Calculation of sand-aggregate ratio and water dosage of ordinary concrete. Cem. Concr. Res. 2002, 32, 431-434. [CrossRef]

40. Lydon, F.D. Effect of coarse aggregate and watercement ratio on intrinsic permeability of concrete subject to drying. Cem. Concr. Res. 1995, 25, 1737-1746. [CrossRef]

41. Juradin, S.; Radović, T. Comparison of Methods of Dosage and Effect of the Composition on the Properties of Fresh and Hardened Self-Compacting Concrete. Solid State Phenom. 2016, 249, 131-135. [CrossRef]

42. Kwan, A.K.H.; Chen, J.J. Adding fly ash microsphere to improve packing density, flowability and strength of cement paste. Powder Technol. 2013, 234, 19-25. [CrossRef]

43. Sha, F.; Li, S.C.; Liu, R.T.; Li, Z.F.; Zhang, Q.S. Experimental study on performance of cement-based grouts admixed with fly ash, bentonite, superplasticizer and water glass. Constr. Build. Mater. 2018, 161, 282-291. [CrossRef]

44. Mehdipour, I.; Khayat, K.H. Effect of particle-size distribution and specific surface area of different binder systems on packing density and flow characteristics of cement paste. Cement. Concr. Compos. 2017, 78, 120-131. [CrossRef]

45. Kondraivendhan, B.; Bhattacharjee, B. Flow behavior and strength for fly ash blended cement paste and mortar. Int. J. Sustain. Built. Environ 2015, 4, 270-277. [CrossRef] 
46. Jiang, D.B.; Li, X.G.; Lv, Y.; Zhou, M.K.; He, C.H.; Jiang, W.G.; Liu, Z.L.; Li, C.J. Utilization of limestone powder and fly ash in blended cement: Rheology, strength and hydration characteristics. Constr. Build. Mater. 2020, 232, 117228. [CrossRef]

47. Zheng, K.; Yang, X.; Chen, R.; Xu, L. Application of a capillary crystalline material to enhance cement grout for sealing tunnel leakage. Constr. Build. Mater. 2019, 214, 497-505. [CrossRef]

48. Zhang, C.; Fu, J.Y.; Yang, J.S.; Ou, X.F.; Ye, X.T.; Zhang, Y. Formulation and performance of grouting materials for underwater shield tunnel construction in karst ground. Constr. Build. Mater. 2018, 187, 327-338. [CrossRef]

49. Shi, C.J. Strength, pore structure and permeability of alkali-activated slag mortars. Cem. Concr. Res. 1996, 26, 1789-1799. [CrossRef]

50. Deo, O.; Neithalath, N. Compressive behavior of pervious concretes and a quantification of the influence of random pore structure features. Mat. Sci. Eng. A 2010, 528, 402-412. [CrossRef]

51. Awadalseed, W.; Zhang, J.; Zhao, H.H. Experimental Study on Nano SiO2 and Cement Modified Expansive Soil. In Proceedings of the GeoShanghai 2018 International Conference: Fundamentals of Soil Behaviours, Shanghai, China, 27-30 May 2018; pp. 209-217.

(C) 2020 by the authors. Licensee MDPI, Basel, Switzerland. This article is an open access article distributed under the terms and conditions of the Creative Commons Attribution (CC BY) license (http://creativecommons.org/licenses/by/4.0/). 